\title{
マルチロータ機の性能向上に関する一検討
}

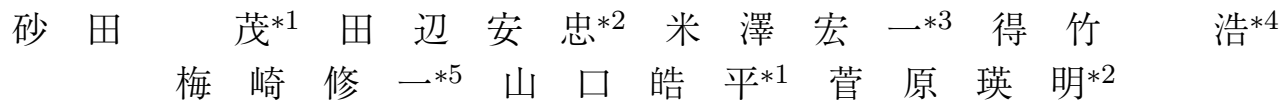

\section{A Study on Improvement of Performance of a Multiple Rotor Drone}

\author{
Shigeru Sunada*1, Yasutada Tanabe*2, Koichi Yonezawa*3, Hiroshi Tokutake*4, \\ Shuichi Umezaki*5 ${ }^{* 5}$ Kohei Yamaguchi*1 and Hideaki Sugawara*2
}

\begin{abstract}
The following three points have been investigated for improving the flight performance of a multiple rotor drone. The first one is 'collective pitch control', which enables rotors to change the thrust much quicker than the rotor speed control method. Furthermore, a negative thrust can be generated by the rotors with a negative collective pitch. The negative thrust can cause a large control moment for controlling the attitude. Then, the drone has high maneuverability thanks to the quick thrust change due to the collective pitch control. The second one is 'decreases of the moments of inertia', which can enhance the maneuverability of the drone. The variation of moments of inertia has also possibility to decrease a motion of the drone due to a disturbance moment when a feedback control is adopted. The third one is 'a rotor with small aspect ratio rotor blades', which generates a larger thrust caused by the larger chord length and the larger thrust coefficient.
\end{abstract}

Key Words: Drone, Collective Pitch, Moment of Inertia, Low Aspect Ratio Blade

\section{1.は じめに}

Fig. 1 は, 名古屋大学博物館に展示されている, エンジンに よるクアドロー夕機である，機体中央に位置するエンジンで 4 ロータが回転し，コレクテイブピッチは各ロータに付いたサー ボモータで変化する.コレクティブピッチ変化だけではヨーの コントロールモーメントが不足するので，ロータ下のベーンの 角度をサーボモータで調節し，ヨーイングモーメントを発生さ せる. この機体は 1988 年, 名古屋大学 (鈴木正之名誉教授, 丹 羽昌平講師 (当時), 杉浦一郎名誉教授）と日立造船（株）との 共同研究によって開発されたもので, 名古屋大学博物館に展示 されている (Nagoya University Museum Ta00063)。この機 体を含め従来の航空機では, 翼の迎角や形状（舵面を指す）を 変化させ，主に揚力を変化させ飛行を制御している．揚力と迎 角との関係に線形性があること，迎角を変化させるために大き な仕事を要さないこと, 迎角の变化が短時間で可能であること がその背景にある.

現在のマルチロータ機のほとんどは，コレクティブピッチ変

原稿受付 2020 年 3 月 16 日

*1 名古屋大学

$* 2$ 宇宙航空研究開発機構

*3電力中央研究所

$* 4$ 金沢大学

$* 5$ 大阪府立大学

${ }^{* 1}$ Nagoya University

*2 Japan Aerospace Exploration Agency

${ }^{* 3}$ Central Research Institute of Electric Power Industry

${ }^{* 4}$ Kanazawa University

${ }^{* 5}$ Osaka Prefecture University

—本論文は提案性（システム設計・構築分野）で評価されました。

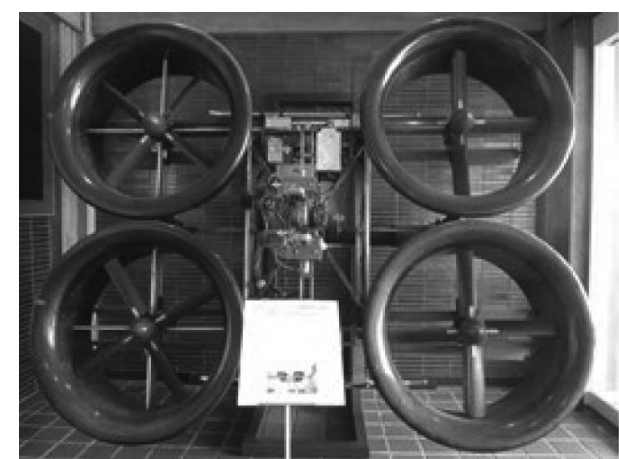

Fig. 1 Multicopter developed by Nagoya University and Hitachi Zosen Corporation (1988)

化でなく, 各ロータに付いたモータの回転数変化によって飛行 をコントロールする．回転数変化方式は，ピッチ角の変化方式 に比べ, 部品点数が少なく構造がシンプルで安価であるという メリットを持つ. また, 下記のようにピッチ角方式では機体運 動の制御のためのヨーイングモーメントが十分でなく，ヨーイ ング運動コントロールのため回転数変化も併用する必要がある. 回転数方式は, ピッチ角変化方式との併用を必要としない点も メリットである。一方，これまでのへリコプターにおけるピッ 于角変化方式の優れた特徴を鑑み, 我々のグループでは内閣府 ImPACT タフ・ロボ・ティクスチャレンジの一研究として, ヨー イングモーメント発生のための回転数変化に加え, コレクティ ブピッチ変化方式も用いるドローンの研究「ミニサーベイヤー の機動性・安全性向上, 飛行時間延長に関する研究」に取り組ん だ [1] [2]. 特に, 橋梁点検等, 壁や物体の近くで飛行し, 高周波 数の風擾乱を受ける際にドローンを活用できるよう， (1)コレク 
ティブピッチ変化の導入 $[3] 〜[6]$, (2)原動機の集約化（慣性モー メントの変化), (3)低アスペクト比ブレードの採用, について定 量的データを示した．将来のマルチロータ機の高性能化のため に，これら要素技術が利用されることをねらっている。(2)の慣 性モーメントの変化を数值的に把握する際，実際の機体での数 值の変化が必要であり，開発した二つのマルチロータ機， 1 号 機 (Multiple Rotor drone ImPACT1: MR. ImP-1) [1], 2 号 機（MR. ImP-2） [2] を例にする。また，これらの機体には(1), (3)も取り达まれている.

\section{2. 開 発 機 体}

\subsection{1 号機 一コレクティブピッチ制御の導入}

Fig. 2 に 1 号機を示す. また, Fig. 3 に本機体で用いられた ピッチ変更モジュールを示す。このモジュールは元来，JAXA コンパウンドヘリ実験機用 $[7]$ に開発されたもので, それを本機 体に転用した。モジュールはロー夕を回転をさせるDCブラシ レスモータとピッチを変更するサーボモータとからなる。ロー タの詳細については後述するが, ブレードはスパン方向にねじ りがなく，対称翼型（NACA0009）を持つとし，ホバリングで はピッチ角の変更によって上下両方向に同等の推力が発生可能 にした。この機能により, 沈下速度の小さな不安定な飛行領域 を短時間で回避可能である，また，負の推力の発生は，大きな 姿勢コントロールモーメント発生につながる.

コレクティブピッチ変化およびスパン方向にねじりのないブ レードの採用は，ロータが自動回転（風車）モード，駆動回転 (プロペラ）モードの両方でロータが用いられるオートローテー ション [8] に適している. 後述の 3.2 節で述べるが, 本機体の 1 ロータの推力発生をインパルシブな信号入力によって $5.5[\mathrm{~N}]$ か ら $9.6[\mathrm{~N}]$ に変更した場合, 信号入力から推力定常值飽和までの 時間遅れで見ると, ピッチ変化方式は回転数変化方式に対し，6

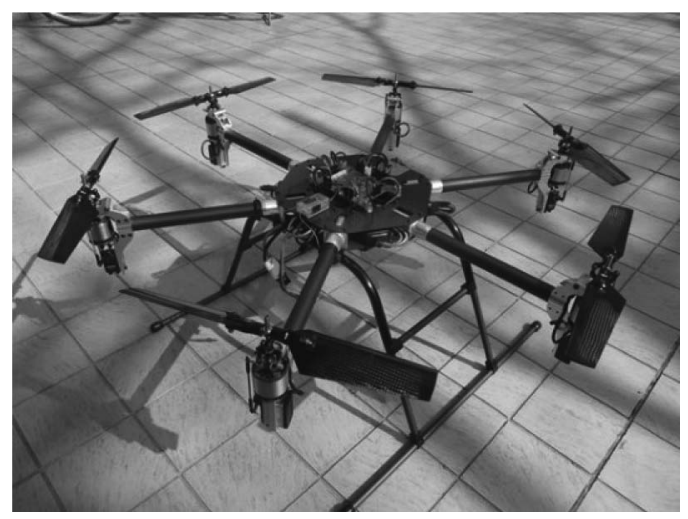

Fig. 2 MR. ImP-1 [1]

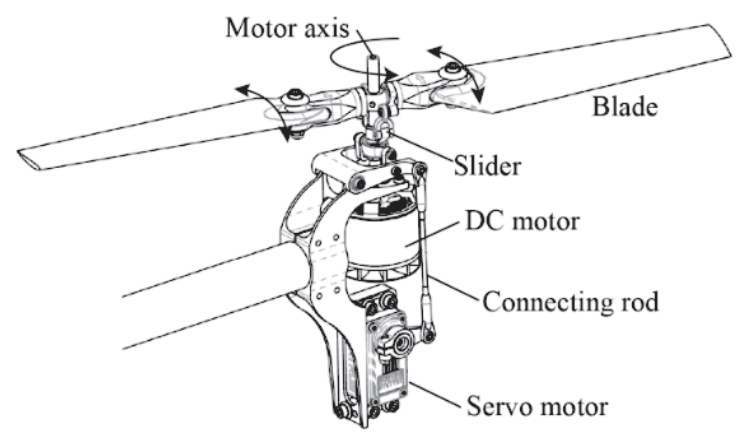

Fig. 3 Module for controlling collective pitch [7]
倍以上高い応答速度を達成している。

我々のグループが 1 号機を発表したのは 2016 年 4 月の第 2 回国際ドローン展であったが，ほぼ同時期に国内でもピッチ角 方式ドローンを発表した企業もあった [9]. なお，我々の開発機 体において，ヨーの運動を制御するためには，コレクティブピッ チ変化でなく回転数変化を主に利用している，翼は低迎角にお いて抗力係数に対する迎角の感度が小さく，低迎角では迎角を 変化させても大きなヨーイングコントロールモーメントを発生 できないためである.ヨーイングコントロールモーメント発生 のために，上方から見て時計回りのロータと反時計回りのロー タで回転数差をつけている.

本機体ではコレクティブピッチ，回転数の両方を変化させる ことで, 最大推力や最大コントロールモーメントを大きくする ことが可能である。また各発生推力で適当なコレクティブピッ チと回転数の組み合わせを選択し, 効率を高めることも可能で ある、この様に開発機体は，コレクティブピッチ変化と回転数 変化の混合方式である.

\subsection{2 号機の開発 —モータの集約化（慣性モーメントの} 変化)

我々のグループは，1号機の改良をさらに進めた．Fig. 4 に 2 号機 [2] を示す. 1 号機からの変更点は以下のとおりである.

（1）ロータと機体中央部を連結するアームの下方にロータが位 置するようにした。

（2） 1 号機では 6 個であったモー夕を，上から見て時計回りに 回転する 3 ロー夕用のモータと，反時計回りに回転する 3 ロータ用のモータの二つに集約し, 機体重心付近に配置し た。モータとロータ回転軸はべルトで連結され, モータの 駆動力が各ロータに伝達される.

（1）について：通常の飛行ではロー夕は鉛直上向きの推力を発 生し，誘導速度は鉛直下向きである。この変更によって，誘導 速度のためにアームに働く鉛直下向きの抵抗を減らすことがで きる.（2）について：モータの集約化は, 同じ方向に回転する 3 ロータの回転数を同一にできるピッチ変化方式を採用したため 実現可能になったものである。なお，各ロー夕用のサーボモー 夕はアームの上に固定した. この結果, Table 1 が示すように, 機体の重量は $300[\mathrm{~g}]$ 程減少したが，この減少はモー夕の総重量 の減少分（約 $270[\mathrm{~g}]$ ) にほぼ一致する，また，機体のすべての 軸回りの慣性モーメントは 1 号機での值の約半分にすることが できた。

小さな慣性モーメントは同一のコントロールモーメントによっ て生じる角加速度が大きいことを意味しており，マヌーバ性能 の向上につながる。またフイードバック制御も考慮すると以下

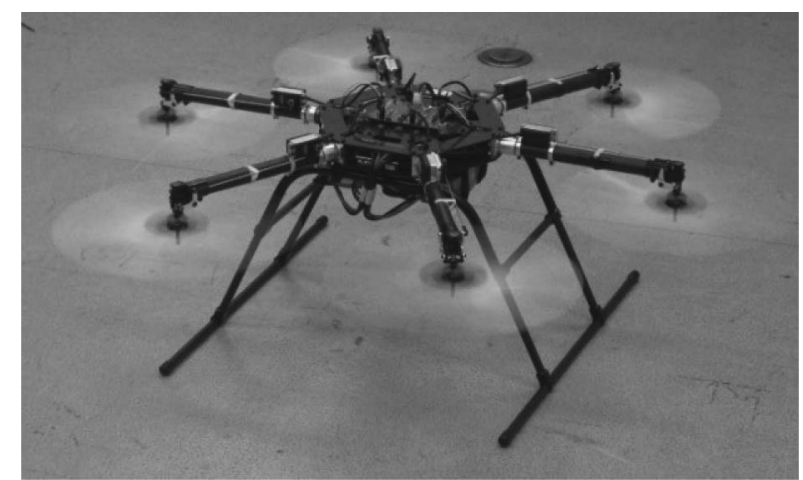

Fig. 4 MR. ImP-2 [2] 
のように，慣性モーメントを小さくすることが擾乱モーメント 遭遇時の姿勢角変化を抑えることにつながる可能性もある．簡 単のため, ホバリング時の $x-z$ 面内の運動を考えるが, 対称性 から $y-z$ 面内の運動もほぼ同一の議論が可能である. $y$ 軸回り の運動方程式は,

$$
\begin{aligned}
I_{y} \ddot{\theta}(t) & =\left(M_{q} \dot{\theta}(t)+M_{u} u(t)\right)+M(t)+D(t) \\
& \approx M_{q} \dot{\theta}(t)+M(t)+D(t)
\end{aligned}
$$

で与えられる，ここで， $I_{y}$ : 慣性モーメント， $\theta$ : ピッチ角， $M$ : フィードバック入力モーメント, $D$ : 擾乱モーメント, $M_{q}, M_{u}$ は有次元安定微係数である. $u, q$ はそれぞれ $x$ 方向の速度, $y$ 軸回りの角速度で, 有次元安定微係数 $M_{q}, M_{u}$ は通常のテキス トで定義される有次元安定微係数 [10] に慣性モーメント $I_{y}$ を かけた值である.

この式をラプラス変換し，一次遅れを含むピッチ角に対する $\mathrm{PD}$ 制御を考えるものとするとし，次式で $M(s)$ を与える.

$$
M(s)=\frac{1}{T s+1}\left(-K_{D} s \theta(s)-K_{p} \theta(s)\right)
$$

ここで, $K_{D}, K_{p}$ はそれぞれ, $\dot{\theta}(s), \theta(s)$ に対するフィードバッ クゲインである.このとき, ピッチ角 $\theta(s)$ と擾乱モーメント $D(s)$ の間の伝達関数は

$$
G(s)=\frac{T s+1}{s\left(s I_{y}-M_{q}\right)(T s+1)+K_{D} s+K_{p}}
$$

で与えられる。なお,

$$
\begin{gathered}
|G(j \omega)|=\sqrt{1+(T \omega)^{2}} / \sqrt{F} \\
F=\omega^{4}\left\{1+(\omega T)^{2}\right\} I_{y}^{2}-2 \omega^{2}\left(K_{p}+K_{D} \omega^{2} T\right) I_{y} \\
\left.+\omega^{4} M_{q}^{2} T^{2}+\omega^{2}\left(M_{q}^{2}+K_{D}^{2}-2 K_{D} M_{q}+2 K_{P} M_{q} T\right)\right\} \\
+K_{P}^{2}
\end{gathered}
$$

\begin{tabular}{|c|c|c|}
\hline & MR. ImP-1 & MR. ImP-2 \\
\hline $\begin{array}{c}\text { Mass } \\
\text { excluding } \\
\text { batteries }(\mathrm{kg})\end{array}$ & 3.5 & 3.2 \\
\hline $\begin{array}{l}\text { Total mass of } \\
\text { motors }(\mathrm{kg})\end{array}$ & 1.00 & 0.73 \\
\hline $\begin{array}{c}\text { Moment } \\
\text { inertia around } \\
\mathrm{x} \text { axis }\left(\mathrm{kgm}^{2}\right)^{*}\end{array}$ & 0.20 & 0.095 \\
\hline $\begin{array}{c}\text { Moment } \\
\text { inertia around } \\
\text { y axis }\left(\mathrm{kgm}^{2}\right)^{*}\end{array}$ & 0.20 & 0.089 \\
\hline $\begin{array}{c}\text { Moment } \\
\text { inertia around } \\
\text { z axis }\left(\mathrm{kgm}^{2}\right)^{*}\end{array}$ & 0.37 & 0.16 \\
\hline
\end{tabular}

Table 1 Comparions of mass and moments of inertia between MR. ImP-1 and MR. ImP-2

*Calculated values based on CAD data, where batteries are excluded.
で，式 (5)より， $K_{p} ， K_{D} ， T$ が与えられた際， $I_{y} \leq\left(K_{p}+\right.$ $\left.K_{D} T \omega^{2}\right) / \omega^{2}\left\{1+(T \omega)^{2}\right\}$ のときは, 慣性モーメントを小さく した際， $|G(j \omega)|$ を小さくすることが可能である，本検討は，擾 乱モーメントによる姿勢擾乱が, 慣性モーメントの増減により 抑制可能であることを示したものである，マヌーバ性能，擾乱 で引き起こされる運動の両面を考慮し最適化するために，慣性 モーメントの変更は有効である.

大型エンジンドローン [11] やモー夕駆動の小型ドローンでも コレクティブピッチ制御を採用し, 駆動源（モータ，エンジン） の集約化を行った機体がある。これらの機体での駆動源の集約 化のねらいは, 主に重量の低減であると考えられ, 慣性モーメ ントの低減による飛行性能の向上をねらいとした本稿のねらい とは異なっている可能性がある.

\section{3. 口 - 夕}

\section{1 定常特性}

1 号機，2 号機において，ロータは低アスペクト比ブレード を使用している，ロータの効率だけを考えると低アスペクト比 ブレードは有利ではない. しかしながら, 要求スラスト, ロー 夕半径の制限がある場合，ワイドコードにし回転数，すなわち 翼端マッハ数を下げたほうが低騒音化の点からは望ましい。ま た， 1 号機， 2 号機では以下の理由で，ロータに低アスペクト 比ブレードを使用している. ロータの平面形，諸元を Fig. 5,

Table 2 に示す.

Fig. 6 にロー夕回転数が $4,000[\mathrm{rpm}]$ のときの推力係数-コレ クティブピッチの関係を示す. 推力係数 $C_{T}$ は

$$
C_{T}=T / \rho\left(\pi R^{2}\right)(R \Omega)^{2}
$$

で与えられる $[13]$. ここで, $T, \rho, \Omega$ は推力, 空気密度, ロー 夕回転角速度である.JAXA の開発したrFlow3D による CFD による結果, 翼素理論／環状運動量理論（BET/AMT）による

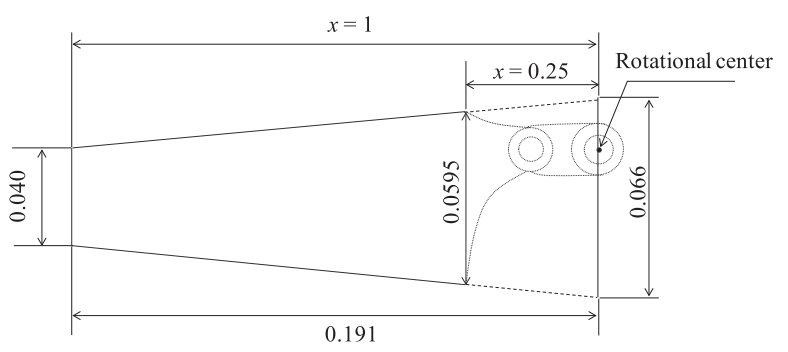

Fig. 5 Planform of rotor blade. The values of $x$ are nondimensionalized by the rotor radius. The unit of the other values is $\mathrm{m}[12]$

Table 2 Properties of a rotor blade [12]

\begin{tabular}{|l|c|}
\hline Airfoil & NACA0009 \\
\hline Radius, $R$ & $0.191 \mathrm{~m}$ \\
\hline Root cut off, $R_{0}$ & $0.0478 \mathrm{~m}$ \\
\hline Root chord & $0.066 \mathrm{~m}$ \\
\hline Tip chord & $0.040 \mathrm{~m}$ \\
\hline Twist angle & 0 degree \\
\hline $\begin{array}{l}\text { Aspect ratio, }\left(R-R_{0}\right)^{2} / S \\
S \text { : Blade area }\end{array}$ & 2.2 \\
\hline
\end{tabular}


計算結果，および測定結果を示す．翼素理論／環状運動量理論に おける計算では， NACA0009 の $R_{e}=2.0 \times 10^{5}$ での翼型デー 夕をXFOIL で求め使用した $[14]$. ここで $R_{e}=\rho U c / \mu$ はレイ ノルズ数で， $U, c, \mu$ はそれぞれ速度，コード長，粘性係数で ある。また，測定はFig. 7 に示す装置を用いて行った。なお， 測定に使用したロードセルは，協和電業 LSM-B-50NSA1-P で ある、ロータの吹き下ろしによる支持アームに働く空気力を抑 えるため，鉛直下向きに推力を発生するようにし，そのときの コレクティブピッチを正の值と定義した.

Fig. 8 にロータの定常特性（推力係数一トルク係数）の実験 結果と CFD 結果との比較を示す. トルク係数 $C_{Q}$ は次式で与 えられる.

$$
C_{Q}=Q / \rho\left(\pi R^{2}\right) R(R \Omega)^{2}
$$

ここで $Q$ は，回転軸回りのトルクである．本測定においてロー ドセルは，日章電機製 LMC-6524-5 を用いた。実験と CFD で の推力係数-トルク係数の関係の一致は良好である. Fig. 8 にお

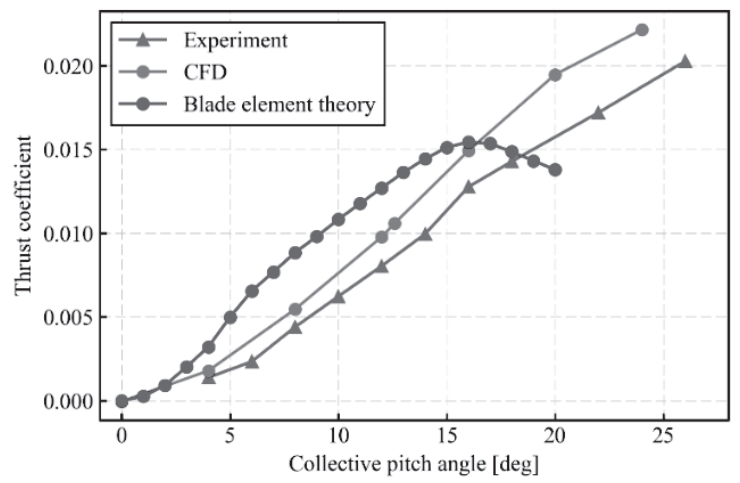

Fig. 6 Steady characteristics of a rotor (Thrust coefficientCollective pitch) $[12]$

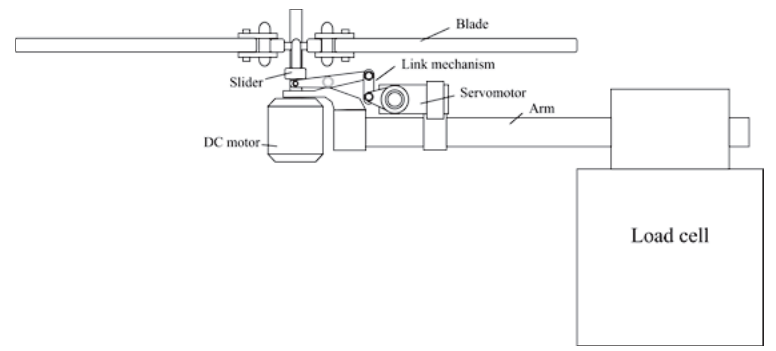

Fig. 7 Experimental apparatuses for measuring steady and unsteady thrust [12]

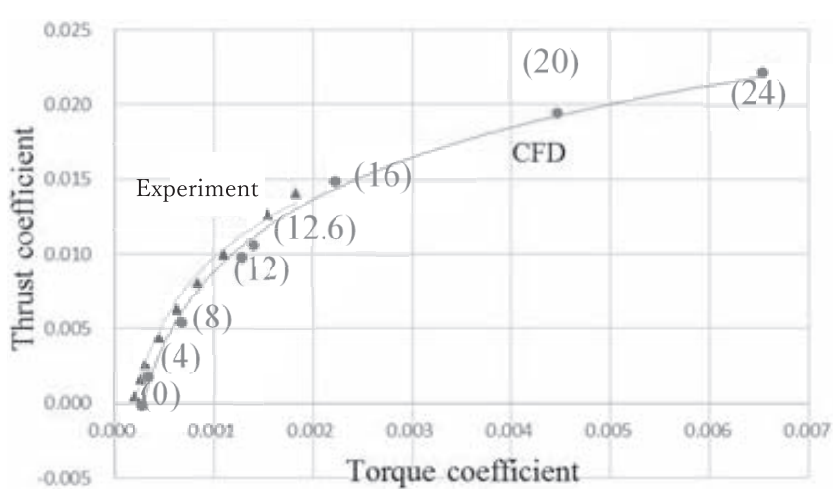

Fig. 8 Steady characteristics of a rotor (Thrust coefficientTorque coefficient). The values in the parentheses are collective pitch angles [12]
ける推力係数一トルク係数の関係における CFD と実験結果の良 好な一致から, Fig. 6 における両者の差は, 実験におけるコレク ティブピッチの測定誤差, すなわちブレード付け根のピッチ方 向のガタやブレードのねじり等によって真のコレクティブピッ チが設定コレクティブピッチの值より小さいことによると推測 できる。

Fig. 6 での翼素理論／環状運動量理論は, 二次元翼の特性を ベースにした高アスペクト比ブレードで高精度の手法である. コレクティブピッチ増加に伴う $C_{T}$ の減少が約 $15[\mathrm{deg}]$ 以上で のコレクティブピッチで見られる．実験， CFD の結果で見られ る大きなコレクティブピッチまでの $C_{T}$ の増加は低アスペクト 比ブレードゆえの現象である，大きなコレクティブピッチまで の推力係数の増加は低アスペクト比ブレードを有する回転翼の 特徵 [15] として知られるものであり，この特性はコレクティブ ピッチ方式の機体において有利なものである.

\section{2 ステップ入力信号に対する推力出力}

回転数, コレクティブピッチ変化時の推力の過渡変化を比較 検討するために，モータにステップ状の信号を入力し回転数を 変化させた場合，サーボモータにステップ状の信号を入力しコ レクティブピッチを変化させた場合での推力変化を比較した.

Table 3 に推力を増加させる場合 (Case 1), 減少させる場

Table 3 Test cases for comparisons between collective pitch control and rotational speed control

\begin{tabular}{|c|c|c|}
\hline \multicolumn{3}{|c|}{ Case 1} \\
\hline & Collective pitch & Rotational speed \\
\hline Thrust $(\mathrm{N})$ & 5.5 & 9.6 \\
\hline $\begin{array}{l}\text { Collective } \\
\text { pitch (deg) }\end{array}$ & $10 \rightarrow 14.3$ & 10 \\
\hline $\begin{array}{l}\text { Rotational } \\
\text { speed (rpm) }\end{array}$ & 4000 & $4000 \rightarrow 5500$ \\
\hline $\begin{array}{l}\text { Duration for } \\
\text { [collective } \\
\text { pitch or } \\
\text { rotational } \\
\text { speed] change } \\
\text { (s) }\end{array}$ & 0.049 & 0.42 \\
\hline $\begin{array}{l}\text { Power } \\
\text { estimated } \\
\text { from propeller } \\
\text { torque (W) }\end{array}$ & $79 \rightarrow 141$ & $79 \rightarrow 205$ \\
\hline \multicolumn{3}{|c|}{ Case 2} \\
\hline & Collective pitch & Rotational speed \\
\hline Thrust (N) & 9.6 & 5.5 \\
\hline $\begin{array}{l}\text { Collective } \\
\text { pitch (deg) }\end{array}$ & $14.3 \rightarrow 10$ & 10 \\
\hline $\begin{array}{l}\text { Rotational } \\
\text { speed (rpm) }\end{array}$ & 4000 & $5500 \rightarrow 4000$ \\
\hline $\begin{array}{l}\text { Duration for } \\
\text { [collective } \\
\text { pitch or } \\
\text { rotational } \\
\text { speed] change } \\
\text { (s) }\end{array}$ & 0.053 & 0.45 \\
\hline $\begin{array}{l}\text { Power } \\
\text { estimated } \\
\text { from propeller } \\
\text { torque (W) }\end{array}$ & $141 \rightarrow 79$ & $205 \rightarrow 79$ \\
\hline
\end{tabular}




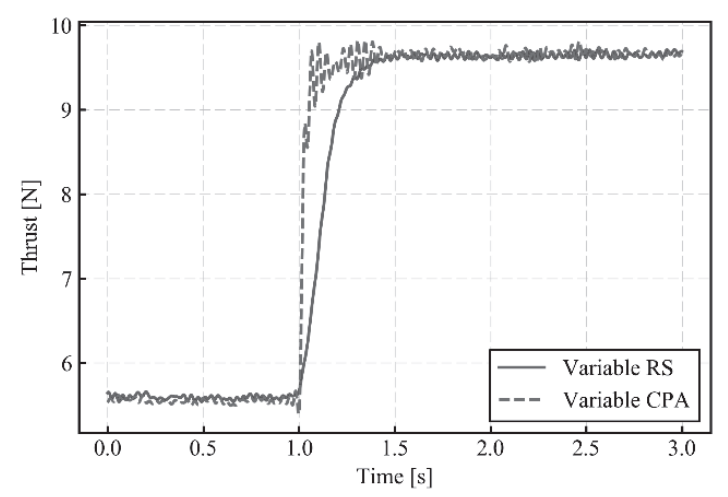

(a) Case 1

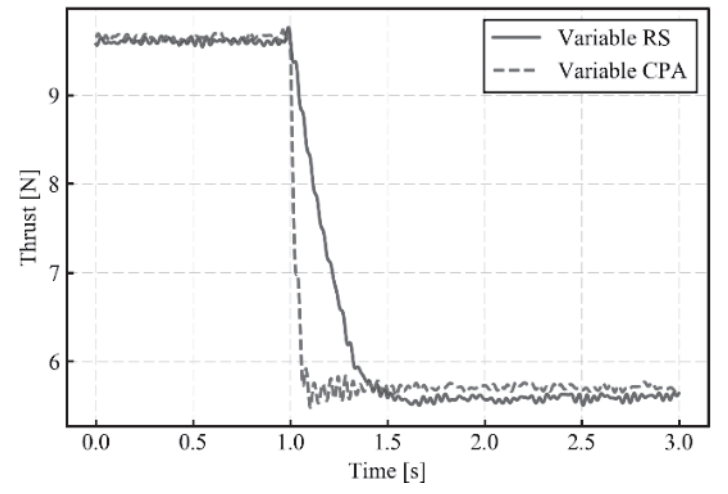

(b) Case 2

Fig. 9 Comparisons of time-variations of thrust between rotational speed control and collective pitch control. RS and CPA means the results of 'rotational speed control' and 'collective pitch control', respectively [12]

合（Case 2）について，回転数変化方式，コレクティブピッチ 変化方式での各種の值を示す。回転数の時間変化は夕コメータ (FT3406，日置電機）で測定した。一方，コレクティブピッチ 変化については, Fig. 7 にあるリンク機構の運動を高速度カメラ で撮影し求めた。 また，変化前後のコレクティブピッチは非回 転時にピッチゲージで測定した，なお，短い時間での推力変化 を求める実験となるため, 推力変化に対するロードセルの影響 を事前に評価した。ロードセル (共和電業 LSM-B-50NSA1-P) を二次遅れ系と仮定し, 焼き切り試験の結果から実験のシステ 厶を同定した。その結果, 減衰率は $\zeta=0.195$, 固有角振動数 は $\omega_{n}=890[\mathrm{rad} / \mathrm{s}]$ で, ロードセルの固有角振動数は本測定 において十分高い值であることを確認した。測定值は $30[\mathrm{~Hz}]$, $60[\mathrm{~Hz}](\fallingdotseq 180[\mathrm{rad} / \mathrm{s}], 360[\mathrm{rad} / \mathrm{s}])$ のローパスフィルタで処理 したが，どちらのローパスフィルタを用いた場合でも，推力が定 常值に達するまでの時間に大きな差はみられなかった. Fig. 9 に，ローパスフィルタ $30[\mathrm{~Hz}]$ のときの Case 1, Case 2 の結 果を示す. Fig. 9 および Table 3 が示すとおり, コレクティブ ピッチ変化方式は, 回転数変化方式と比較して, 6 倍以上高速 な推力変化を達成した，モータ集約化による慣性モーメントの 半減と合わせて, 姿勢角において 12 倍以上の角加速度の発生 が可能となる.

失速角を超える大きな迎角において，短い時間で運動速度や 迎角が変動した場合，準定常の揚力を超える大きな非線形非定 常揚力が翼に働くことが知られている (ワグナ効果) [16]. しか し, Fig. 9 に示す実験結果では，この現象が見られない.これ は，本実験のコレクティブピッチが Fig. 6 に示す推力ーコレク
Table 4 Advantages due to collective pitch mechanism and a low aspect ratio rotor

\begin{tabular}{|l|l|}
\hline $\begin{array}{l}\text { Collective } \\
\text { pitch method }\end{array}$ & $\begin{array}{l}\text { (1) } \text { (i) Control forces and moments } \\
\text { varying quickly. } \\
\text { (ii) Large control moments due to } \\
\text { possible negative thrust. Possible } \\
\text { large descending velocity due to large } \\
\text { negative thrust. } \\
\text { (iii)Small moments of inertia due to } \\
\text { motors close to the center of gravity of } \\
\text { the multirotor. } \\
\text { (2)A possibility of small disturbed } \\
\text { motion due to the small moments of } \\
\text { inertia stated in (iii). } \\
\text { (3)A possibility of autorotation. }\end{array}$ \\
\hline $\begin{array}{l}\text { A low aspect } \\
\text { ratio blade }\end{array}$ & $\begin{array}{l}\text { 1) monotonous relation between a } \\
\text { collective pitch and a thrust coefficient } \\
\text { under a wide region of a collective } \\
\text { pitch angles. A high thrust coefficient } \\
\text { at a high collective pitch angle. } \\
\text { (2) Small noise due to a low tip Mach } \\
\text { number. }\end{array}$ \\
\hline
\end{tabular}

ティブピッチの関係 (実験もしくは CFD) において, コレクティ ブピッチの増加とともに推力係数が増加する範囲に収まってい るためである.コレクティブピッチ変化方式では, コレクティ ブピッチが大きくなる可能性がある. 低アスペクト比ブレード を用いることで，コレクティブピッチ増加に伴い推力係数が増 加する範囲にコレクティブピッチが入り，大きな非線形非定常 揚力が働かないことにつながる。このことは，マルチロータ機 の振動やブレードの破損を抑制する効果が期待できる点から望 ましい.

上記，コレクティブピッチ方式，低アスペクト比ブレードに よるマルチロータ機の高性能化を Table 4 にまとめる.

\section{4. ま と め}

応答の速いコレクティブピッチ変化方式の採用，またそれに よって可能になる負の推力発生，これらによって短時間で大き な推力, コントロールモーメントの発生が可能になる.コレク ティブピッチ変化方式の採用でオートローテーションの可能性 が生まれる，オートローテーションを考えると，ロータが自動 回転 (風車) モード, 駆動回転 (プロペラ) モードの両方でロー 夕が用いられるため, スパン方向にねじりのないブレードは適 している，また，モータの 2 個への集約化，中央配置による慣 性モーメント低下は，コントロールモーメント発生時の角加速 度を大きくするのでマヌーバ性能の向上につながる。モー夕を 2 個にしたのは，上方から見て時計・反時計方向に回転するロー 夕を別々のモータで回転し回転数差をつけられるようにし，大 きなヨーイングモーメントを発生可能にするためである. 一方, フィードバック制御も考慮に含めた場合，慣性モーメントを小 さくすることが, 擾乱モーメントによる姿勢擾乱を抑える効果 を持つ可能性もある.

推力や姿勢制御モーメントの最大值は，ロータが失速する際 の最大推力に依存する，ロータ半径が限定されているとき，角 速度の増大よりもブレードのアスペクト比の減少が，大きな最 大推力のために，あわせて低騒音化のために有効である.ここ でアスペクト比の減少は，コードの増大だけでなく，低アスペ 
クト比ゆえの高コレクティブピッチでの高推力係数を意味する.

謝 辞 本研究は, 革新的研究開発プログラム ImPACT の 支援を受け，実施したものである.

\section{参 考 文 献}

[1] S. Sunada, Y. Tanabe, K. Yonezawa and H. Tokutake: "Improvement of flight performance of Minisurveyor by using pitch control and decreasing the number of rotors," Proc. of the 2016 Asia-Pacific International Symposium on Aerospace Technology, p.3, 2016.

[2] Y. Tanabe, K. Yonezawa, H. Tokutake, S. Suzuki, K. Yamaguchi and S. Sunada: 'A Study on Enhancing the Agility and Safety and on Increasing the Flight Duration of a Multiple Rotor Drone,' Disaster Robotics (Edited by S. Tadokoro). pp.111122, Springer Verlag, 2019.

[ 3 ] M. Cutler, N.K. Ure, B. Michini and J.P. How: "Comparison of fixed and variation pitch actuators for Agile quadrotors," AIAA Guidance, Navigation, and Control Conference, pp.1-17, 2011.

[4] M. Cutler and J.P. How: "Actuator constrained trajectory generation and control for variable-pitch quadrotors," AIAA Guidance, Navigation, and Control Conference, pp.1-15, 2012.

[5] M. Cutler: Design and control of an autonomous variable-pitch quadrotor helicopter, Master's thesis, Massachusetts Institute of Technology, Department of Aeronautics and astronautics, 2012 .

[6] http://drone-next.jp/special/e-report/tkk/ (accessed July 29, 2020)

[ 7 ] Y. Tanabe, T. Aoyama, N. Kobiki, M. Sugiura, R. Miyashita,
S. Sunada, K. Kawachi and M. Nagao: A Conceptual Study of High Speed Rotorcraft, European Rotorcraft Forum, Southampton, UK, Paper \#081, 2014.

[ 8 ] 柴田倖汰, 山口皓平, 砂田茂, 得竹浩, 長谷悠陽, 田辺安忠, 米澤宏 一：“クアッドロータ機の垂直オートローテーションの可能性検討”, 第 51 回流体力学講演会/第 37 回航空宇宙数值シミュレーション技 術シンポジウム, p.9,2019.

[ 9 ] 平井雅尊, 田徹治, 加藤直也：“非 GNSS 環境で高精度自動飛行する UAV"，日本機械学会誌，vol.121，no.1200，pp.24-25, 2018 .

[10] 加藤寞一郎, 大屋昭男, 柄沢研二：航空機力学入門. 東京大学出版会, 1982.

[11] 中村幹男, 大橋俊夫, 市川純章, 喜多一, 岩瀬将美：“エンジンドロー ンの開発", 日本ロボット学会誌, vol.34, no.2, pp.127-130, 2016

[12] 梅崎修一, 砂田茂, 山口晧平, 菅原瑛明, 田辺安忠, 米澤宏一, 得竹 浩：“コレクティブピッチ変化型マルチロータドローンにおける低ア スペクト比ロータの空力特性について”, 第 51 回流体力学講演会/第 37 回航空宇宙数值シミュレーション技術シンポジウム予稿集, p.7, 2019.

[13] J. Seddon and S. Newman: Basic Helicopter Aerodynamics, Second Edition, AIAA Education Series, AIAA, Inc. Reston, VA, 2001.

[14] http://airfoiltools.com/airfoil/details?airfoil=n0009sm-il (accessed Nobember 7, 2019).

[15] H. Schlichting: Boundary-Layer theory. pp.692-695, McGrawHill, 1979.

[16] A.R. Jones and Babinsky: "Unsteady lift generation on rotating wings at low Reynolds numbers. Journal of aircraft", vol.47, no.3, pp.1013-1021, 2010.

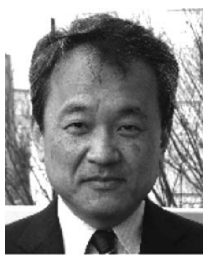

砂田 茂（Shigeru Sunada）

1992 年東京大学大学院博士課程修了. 博士 (工学). 科学技術振興機構グループリーダ，産業技術総合研 究所主任研究員, 大阪府立大学大学院准教授, 同教 授，2017 年より名古屋大学大学院工学研究科航空 宇宙工学専攻教授，現在に至る. 航空工学に興味を 持ち, 羽ばたき翼, 回転翼, 固定翼での飛行に関す る研究を行っている. 日本航空宇宙学会, AIAA 会員.

(日本ロボット学会正会員)

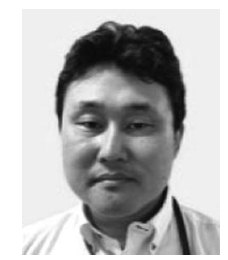

米澤宏一 (Koichi Yonezawa)

2006 年博士 (工学) 大阪大学. 大阪大学大学院基 礎工学研究科助教を経て 2017 年より (一財) 電力 中央研究所. 地球工学研究所流体科学領域主任研究 員．流体機械内部の流動解析，eVTOL を用いた電 カインフラ点検システムの研究開発に従事. 日本機 械学会, 日本航空宇宙学会, ターボ機械協会会員.

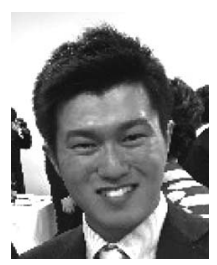

梅崎修一 (Syuichi Umezaki)

2018 年大阪府立大学大学院航空宇宙海洋系専攻修 士課程修了．現在 $\mathrm{ABB}$ 株式会社で産業用高圧モー 夕の設計販売に従事している.

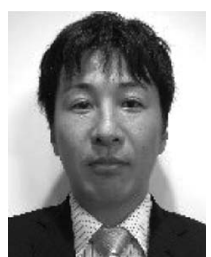

菅原瑛明（Hideaki Sugawara）

2007 年名城大学理工学部卒業. 株式会社菱友シス テムズに入社. 現在東京農工大学博士後期課程, 宇 宙航空研究開発機構で回転翼航空機の空力解析支援 業務に従事。回転翼 CFD ツールの開発を行ってい る. 日本航空宇宙学会会員.

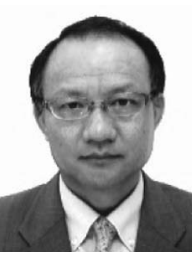

田辺安忠（Yasutada Tanabe）

1989 年九州大学大学院博士課程修了. 博士 (工学). 川田工業株式会社勤務を経て, 2006 年から宇宙航 空研究開発機構. 航空技術部門航空システム研究 ユニット研究領域主幹. 回転翼航空機の空力弾性騷 音連成解析，アクティブ制御による回転翼騷音低減 技術，高速コンパウンドヘリコプターの研究開発を 行っている. VFS 会員, 日本航空宇宙学会会員.

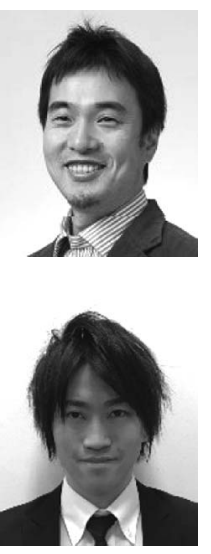

会員.

\section{得竹 浩 (Hiroshi Tokutake)}

2003 年博士 (工学) 名古屋大学. 大阪府立大学工 学部助教, 金沢大学理工研究域准教授, 2018 年同教 授, 現在に至る. 飛行制御の研究に従事. 日本航空 宇宙学会, 計測自動制御学会, 自動車技術会, AIAA 会員.

\section{山口皓平 (Kohei Yamaguchi)}

2017 年京都大学大学院工学研究科電気工学専攻博 士課程修了. 博士 (工学)。 2015 年日本学術振興会 特別研究員, 2017 年名古屋大学大学院工学研究科 航空宇宙工学専攻特任助教， 2018 年同助教，現在 に至る. 宇宙機の軌道最適化，航空機の飛行制御関 連の研究に従事. 日本航空宇宙学会, 日本機械学会 